\title{
COLLECTION AGENCY ACTIVITIES: THE PROBLEM FROM THE STANDPOINT OF THE AGENCIES
}

\author{
E. H. LOTHIAN*
}

Some definitions are in order at the outset. What is the problem? Briefly, it may be stated as the determination of what functions of a collection agency are proper and do not constitute unauthorized practice of the law. What is a "collection agency"? Perhaps it can be defined simply as an individual, a company, or an organization that is engaged in the business of adjusting accounts for creditors. It is necessary, however, to outline the functions of a collection agency in order to see what the problem is. There are many kinds of collection agencies, some reputable and honest and well financed-some quite the reverse. We shall attempt to describe the actual operation of a reputable collection agency as it is or ought to be. It will be necessary also to explain some of the weaknesses and actual acts of commission which deserve correction.

In the course of this discussion, it would not be fair to refrain from mentioning some reasons for the existence of collection agencies. Nor would it be right to fail to mention some functions of collection agencies that grew out of a demand and that have not been performed well by others. Neither would it be proper to omit some references to the position of the lawyer and his ethical viewpoint. In any approach to this subject, moreover, the reader should know that the reputable lawyers of the nation have for years wished to protect the profession and the public from evils growing out of "unauthorized practice of the law." The activities of lawyers have grown more intense in recent years. New laws have been introduced in state legislatures. Injunction suits have been filed. Bar association committees have passed rules and regulations and have had hearings and conferences. Many states have adopted the plan of the "integrated bar," which has implemented such activities. The operations of trust companies, automobile associations, insurance companies, collection agencies and many other organizations have been under review. Collection agencies have not been singled out for attack, but have been merely among the organizations attacked.

Some of the things that collection agencies do that are permitted by statute or court decisions in some states are attacked in other states. Some of the ordinary functions performed generally by nearly all collection agencies are admitted to have been improper. Some other things are not considered wrong by either the creditor or the agency but have been considered so by certain lawyers and have been construed so by some courts. Courts have made little distinction between reputable agencies and

* Director, Adjustment Bureau Department, National Association of Credit Men. 
those which are not reputable. There is much difference of opinion about exactly what constitutes unlawful or unauthorized practice of the law. There is much hazy and poorly-directed thinking among agencies, creditors, lawyers and courts. Prejudice, self-interest, incomplete information and cupidity have had their places in the controversies.

To outline the regular service performed by the ordinary reputable collection agency for its employers, let us take a typical credit transaction and follow it through to a conclusion. The illustration is simply to describe the usual steps in an average wholesale collection and it is not to be considered in the light of any special state statutes or supreme court decisions, although it must be understood that in actual practice there are special conditions that now apply in certain states of the nation, by virtue either of statutes or judicial rulings.

The creditor sells merchandise or performs a service for someone else on credit and thus a debt is created. If the debt is not adjusted according to terms the creditor proceeds to try to secure settlement and if he has difficulty he may decide to employ a collection agency. Collection agencies have various terms for service but the charges are generally contingent upon collection, and in the ordinary wholesale collection they have been approximately $15 \%$ although special terms either higher or lower than this may be offered by the agency or arranged by it. We shall use this $15 \%$ as a convenient and the customary figure.

The creditor usually sends to the agency a simple statement of his account with the debtor. The agency attempts by personal contact or other "lay" means to secure settlement. We use the term "lay" as distinguished from "legal" efforts. In some cases the creditor desires to preserve harmonious relations with his customer. Often it is only necessary for a third party to make the request for payment, whereupon the debtor settles promptly. In other cases the creditor is primarily interested in securing his money and is ready for drastic action, if it is necessary. If the agency obtains settlement by its own efforts it usually remits the proceeds to the creditor after deducting the agreed service charge and the transaction is closed.

The agency, however, may not be able to obtain collection by "lay" effort and may believe that the item should be sent to a lawyer. It informs the creditor of the situation and obtains instructions to place the claim with an attorney. By the custom of many decades, such a claim placed with an attorney has been placed with him by the agency acting as agent for the creditor and the piece of business has been offered to him on the basis of two-thirds of the $15 \%$ fee contingent upon collection. The agency normally retained the other one-third of the $15 \%$ to reimburse it for work done in its previous efforts plus correspondence, reporting, follow-up, and other services. If the attorney was able to secure payment without filing a suit he remitted to the agency, less the two-thirds of the $15 \%$. The agency remitted to the creditor, less its one-third of the $15 \%$, and the transaction was closed.

If the lawyer found that legal proceedings were necessary he notified the creditor or the agency and usually requested that court costs or suit fees or both be advanced to him. The creditor usually advanced these to the agency, and the latter, in turn, 
sent the money to the lawyer. The well-conducted, reputable agency did not attempt to secure any share of such fees. Its compensation came from the one-third of the original collection commission agreed upon. If court costs were recovered they were returned to the creditor intact.

It has been the custom of the agency to select the lawyer from a "law list" and to send him the item of business under the protective bond which is one of the purposes of law lists. The efficient law list company also undertakes to see to it that the lawyers on its list render prompt and efficient service. If a lawyer is careless or dilatory or fails to account for funds collected, the law list company undertakes to get redress for the creditor. Thus, the creditor has been able to send a claim to an agency and expect the item to be serviced to a conclusion. He could close his file, relieve his mind of worry and forget the details. The majority of collection items have been serviced by "lay" service to a conclusion even if, in some cases, a lawyer aided in the work.

Those who choose collection work as their means of earning a living, quite naturally, and nearly always, enjoy the work. Many become unusually proficient. Many develop astonishing ingenuity and resourcefulness. They learn the necessary facts about industrial and economic conditions in various markets. They learn by experience the efficiency of those to whom they "forward" collection items, whether other agencies or attorneys. They become acquainted with the conditions surrounding the chronic debtor. They learn how to help debtors to find the means of payment. Frequently they may arrange a complete reorganization of a debtor's business or methods. Thus they can work in the public interest. They know what papers are necessary when their customer wants legal action taken and are of great help in assembling and securing them for the attorney.

Of course, in the conduct of a business that may have 10,000 or more organizations engaged in it, and that handles several hundred million dollars of accounts receivable in a year, evils can creep in and actually have crept in. Here are some practices that can not be defended; the reputable agency does not engage in:

(a) Splitting legal fees with lawyers.

(b) Using forms or papers that simulate court documents.

(c) Giving legal advice.

(d) Filing suits in courts of record on behalf of others.

(e) Threatening legal proceedings.

(f) Soliciting claims at the instigation of an attorney.

There are other practices that have been used by some agencies to the discredit of all who are engaged in the collection business.

Until September 1937, Canon 34 of the American Bar Association permitted the sharing of a collection commission with a lawyer. The section authorizing such procedure was repealed at the Bar Association's national convention in Kansas City and now reads "No division of fees for legal services is proper except with another lawyer based upon a division of service or responsibility." Some think that this makes it unethical for a lawyer to receive a collection item from a lay agency, when the agency 
participates in the division of the collection commission. They maintain that the collection commission is a legal fee.

The reputable collection agency maintains stoutly that the collection commission is not a legal fee. Unfortunately neither lawyers nor courts have been in agreement on this question. The more enlightened lawyers who have made an extensive study, however, believe that a collection agency of the reputable class can perform a useful service and they do not consider the collection service charge a legal fee. If the agency does some work with reference to a claim and gets one-third of the collection commission, and the lawyer does certain work and gets two-thirds of the collection commission-these facts do not have anything to do with such things as court costs, suit fees, retainers, or other legal fees.

Out of the arguments, suits and controversies, have come a better understanding of the whole problem and the elimination of many abuses. These are some of the things the lawyers wish to see done. They want the creditor to be free to have direct relations with his attorney, if he cares to. The creditor should be free to select his lawyer. The creditor should be told what was paid to the lawyer and what to the agency. If the agency suggests the lawyer's name, it should offer a choice where possible. The lawyers want the agencies to make changes in the wording of their forms to show the above things very clearly. Reputable collection agencies do not object to these things. They are perhaps more anxious than anyone else to let the creditors know the steps in an ordinary collection. It is to the interest of all concerned to have creditors know who the attorneys are-what they do and what they charge for doing it.

Many court decisions of state supreme courts have attempted to point the way to proper and harmonious relations. In some cases, however, these decisions have not seemed to take into account the ordinary and practical relationships between creditor, debtor, creditors' agent and attorney.

How can collection agencies operate in such a way that their useful functions can be continued and also in a manner that will be acceptable to lawyers? One way adopted by certain agencies is somewhat as follows. First, the agency has prohibited the acceptance of any share of any suit fee or legal fee. It has ceased to use any type of advertisement that tends to intimate that it is competent or holding itself out as giving legal advice. When a claim seems to be ready for any legal action it advises the creditor of the whole situation and secures the creditor's instructions. If the creditor wants to have a suit started and if the creditor wants the agency to perform work toward this end, the agency gives to the creditor one or more names of lawyers who have proved their competence in handling such matters. The creditor then selects a lawyer and instructs the agency to proceed with the details. This procedure satisfies the lawyer that the selection of himself is the work of the creditor and the fact that the agency informs him that he may deal directly with the creditor at any stage of the proceedings gives him the direct relationship privilege that is his inherent right.

Hardly any lawyer who is reasonable could object if a creditor selects him but wishes to appoint some one else (the agency) to handle the details, carry on the correspondence, and help in the securing of necessary proofs of a claim. In our own 
opinion, the fact that some lawyers have objected is a reflection upon their knowledge of the practical help the agency can and does perform. The fact that some agencies have gone farther than their function necessitated, may, of course, have something to do with the attitude of certain lawyers.

After all, when an agency has done a great deal of work, has made many personal contacts with a debtor, has spent a considerable amount of time and money on a claim, it is reasonable that the work it has done should have in it much that can be helpful in the final stages of a difficult collection. Agencies do help lawyers very materially. Why shouldn't they? They are like the lawyer in that their compensation for work done is dependent on collection of the account. If they do not collect they do not receive compensation. Some are organized for service to members without much regard to compensation.

Many lawyers have told the writer that they prefer to have experienced collection men in the picture in order to get from the creditor the help needed in handling a claim through one or more courts. It is to be remembered that many credit executives are not familiar with all the steps in enforcing a collection. They are proverbially critical of the (to them) excessive costs involved, and are inexperienced in the mechanics of collection. The intelligent explanations of experienced collection men have done very much to make a creditor sympathetic to the problem of the lawyer.

Of course, when the time comes for legal action, the claim could be returned to the creditor and he could fend for himself from that time forward. But many of the benefits of preliminary work of the agency would be lost. The agency's intimate knowledge of the situation would be wasted. The creditor would not ordinarily be able by experience to know to which lawyer to send the business. Neither, very frequently, would the creditor's own local lawyer. It seems proper to repeat that the collection business is a highly specialized business and that it is no field for amateurs, whether they be lawyers or laymen. Under some of the conditions mentioned herein, it is obvious that the agency can be of inestimable help to both creditor and lawyer, being in a position, by experience, at least to suggest the names of competent lawyers for the creditor's selection.

Some have not known what can be and what is being done by reputable agencies or organizations to insure the proper performance of their offices. We shall confine ourselves to what is done in one very large cooperative organization with some 65 affiliated collection offices. In the first place the affliated organizations wish to render service to members but are under the necessity of at least paying the expenses of such service. This objective is important but is less important than high class, legitimate, ethical, helpful and constructive performance.

Accordingly certain standards of operation are maintained for the protection of everyone. By that we mean that the final objective includes the purpose of seeing to it that any creditor anywhere may receive good service, honestly performed, at a minimum cost. This is the purpose of all legitimate and reputable collection agencies, whether they be individually or cooperatively owned, whether they operate as a single office or as a large company with branches. 
Individuals handling money are adequately bonded and such bonds are inspected and approved by those competent to know. Business and financial operations are studied and supervised by trained management, and by a Board of Directors or, in the case of cooperative organizations, a Committee of Control composed of actual users. Accounts and records are audited by certified public accountants and, often, by "inside" or "supervisory" accountants also. Trust funds are separated from operating funds. Files and interior office conditions are studied as to actual performance and policies. Prompt remittances and scrupulous accounting for all trust funds are the rule in any well conducted agency. All these activities are, of course, in addition to the ordinary mechanics of the handling of the very intimate relationship of creditor and debtor, which have been mentioned heretofore.

There are very many reputable agencies operating in this manner, and it is hardly necessary to point out that if all agencies did likewise, there would be no trouble. It is, we believe, fair to say also that in the actual practice of law by members of the profession, ethical standards have been violated and the policing job has been difficult. We are convinced that the American Bar Association and the reputable. collection agencies are both engaged in a sincere attempt to eliminate unethical and dangerous practices.

The actual existence of collection agencies for so many years should indicate to everyone that they grew out of a need and that they have had the acceptance of the business public. Such a facility does not spring up-full grown-overnight. We have tried to show that it is a specialized business and it is hardly necessary to reiterate that natural aptitude and years of experience are requisites of successful collection men.

The remuneration for collection work is not great. We can say without fear of contradiction that lawyers generally do not enter the profession just to become collection experts. The writer of this article has not met many lawyers who do not prefer other types of work to collection business. It is the personal history of the lawyers of the writer's acquaintance that they prefer to "graduate" from collection work, whenever they are able to do so.

Someone has rightfully said that "evils tend to correct themselves." So it is at this juncture in the collection business. Thoughtful individuals, looking at the "problem" as a whole, have not failed to visualize the ideal condition. We conceive it to be the condition where both collection agencies and lawyers have their places in the business field, complementing the work of each other without conflict, prejudice, fanaticism, misunderstanding or avarice. It is as inevitable that the collection man learn much about law as it is that the lawyer will learn some of the ramifications of collection work. But, in spite of the breadth of knowledge of the law which may be acquired by any individual, no reputable collection agency representative wants to practice law. He is happy to leave this part of a collection transaction to those who are licensed to take care of it in courts of record.

Casual observers will readily admit that much remains to be done on both sides. Conferences and exchanges of views, without rancor or bitterness, continue, as always, to solve such problems. 